\title{
Labour NGOs in China
}

From Legal Mobilisation to Collective Struggle (and Back?)Sida Liu

Ivan Franceschini and Kevin Lin

\section{OpenEdition \\ Journals}

\section{Electronic version}

URL: http://journals.openedition.org/chinaperspectives/8826

DOI: 10.4000/chinaperspectives.8826

ISSN: 1996-4617

\section{Publisher}

Centre d'étude français sur la Chine contemporaine

\section{Printed version}

Date of publication: 20 March 2019

Number of pages: $75-84$

ISSN: 2070-3449

Electronic reference

Ivan Franceschini and Kevin Lin, "Labour NGOs in China », China Perspectives [Online], 2019-1 | 2019, Online since 19 March 2020, connection on 19 December 2020. URL : http://journals.openedition.org/ chinaperspectives/8826 ; DOI : https://doi.org/10.4000/chinaperspectives.8826 


\title{
Labour NGOs in China
}

\author{
From Legal Mobilisation to Collective Struggle (and Back?)
}

\section{IVAN FRANCESCHINI AND KEVIN LIN}

\begin{abstract}
Since their appearance in the mid-1990s, Chinese labour NG0s have mostly focused on three kinds of activities: establishing workers' centres; carrying out outreach programs on labour rights; and conducting social surveys and policy advocacy. Some scholars have strongly criticised this approach, considering it excessively unbalanced towards an individualistic and narrowly legalistic view of labour rights and thus in line with the political agenda of the Party-state. Still, in the past few years, as labour conflict intensified, a handful of labour NGOs have moved forward to adopt a more militant strategy focussed on collective bargaining and direct intervention into worker collective struggles. Based on dozens of interviews with labour activists and workers and detailed analysis of two case studies of NGO-fostered collective labour mobilisation in Southern China in 2014-2015, this paper will outline the personal and political reasons that motivated these organisations to move beyond a narrow legalistic approach and turn towards collective struggles. It will also describe the strategies that Chinese labour activists have adopted in dealing with collective cases. We will conclude by examining the main challenges that labour activists in China have to face when dealing with labour unrest and by questioning the sustainability and feasibility of this new approach in the current political climate.
\end{abstract}

KEYWORDS: labour NG0s, labour rights, labour activism, labour movement, collective bargaining, strikes, civil society, repression, Chinese politics.

I apologise for the losses that my criminal actions have caused to companies, society, and the workers, and I express deep sorrow for the enormous wounds that I have inflicted on my family. I hope that everybody will take me as a warning and that they will not be fooled by any foreign organisation, [keeping in mind] that they must resort to legal means and channels to protect their rights and interests. (1)

t was with these words that in September 2016 labour activist Zeng Feiyang pled guilty to "gathering a crowd to disturb public order" at his trial, an event that marked the peak of the harshest crackdown to hit Chinese labour NCOs since their appearance in the mid-1990s (Franceschini and Nesossi 2018; Froissart 2018). It had all started in December 2015, when public security forces rounded up a couple dozen labour activists in Guangdong, bringing charges against five of them. (2) To signal that this was not a local matter, but a fully-fledged political campaign at the national level, Chinese state media launched a systematic attack against Zeng Feiyang, director of the Panyu Migrant Workers Centre (heretofore simply Panyu Centre), a prominent labour NGO established in Guangzhou in the late 1990s. In a matter of days, CCTV, Xinhua, and People's Daily all published long features in which Zeng was accused of, among other things, embezzling funds illegally obtained from foreign donors and posing as a "star of the labour movement" (gongyun zhi xing 工运之星) while actually acting in contempt of the interests of the workers. ${ }^{(3)}$ All of these reports featured long sections on a high-profile labour mobilisation at Lide, a footwear company that in 2014 was involved in a 14-month-long labour dispute due to the management's decision to relocate production. While the Lide workers had been able to gain a remarkable victory with the help of the Panyu Centre, the authorities went all out to put on display the testimony of a disgruntled former worker representative who accused Zeng and his colleagues of needlessly fomenting worker anger.
Eventually, Zeng Feiyang was sentenced to three years of imprisonment, suspended for four years. Two of his colleagues received prison sentences of 18 months, suspended for two years, on the same charge of "gathering a crowd to disturb social order," while another, a former security guard named Meng Han, was sentenced to 21 months in jail. This landmark case - which took place at the very moment when new laws and regulations that severely constrained NGO access to foreign funding were being implemented (Franceschini and Nesossi 2017) - had a severe chilling effect on Chinese labour NCOs (Franceschini and Nesossi 2018). This raises one question: what are the reasons behind this latest crackdown? After all, labour NGOs have existed in China for two decades, and while state repression has been common since their appearance, it never went so far as to threaten the very existence of these organisations as it does today. In this paper, we argue that one of the most important reasons behind this latest wave of repression is the shift of some labour NGOs from a strictly legalistic approach based on the assertion of the individual legal rights of workers to a longterm political project from below aimed at institutionalising a new system of industrial relations with "worker representation" (gongren daibiao zhi

1. “起底'工运之星'一曾飞洋等人聚众扰乱社会秩序犯罪案件透视” (Qidi “gongyun zhi xing” Zeng Feiyang dengren juzhong raoluan shehui zhixu fanzui anjian toushi, Uncovering the "star of the labour movement" Zeng Feiyang: Exposé on the Criminal Case of Zeng Feiyang and Others Gathering a Crowd to Disrupt Social Order)，法制日报 Fazhi Ribao, 27 September 2016, http://www.legaldaily.com.cn/index_article/content/2016-09/27/content_6817885.htm (accessed on 30 January 2019)

2. "China Arrests Four Labor Activists amid Crackdown: Lawyers", Reuters, 10 January 2017, http://www.reuters.com/article/us-china-rights-idUSKCNOUO05M20160110 (accessed on 30 January 2019).

3. “起底 “工运之星' 真面目” (Qidi “gongyun zhi xing" zhen mianmu, Exposing the true face of the "star of the labour movement"), Renmin Ribao, 23 December 2015, 11; “广东警方打掉维权 组织拘7人, 主犯被称'工运之星'” (Guangdong jingfang dadiao weiquan zuzhi ju qi ren, zhufan bei cheng "gongyun zhi xing," Guangdong police takes down a weiquan organisation and detains seven people: Main culprit was "star of the labour movement"). 新华社 Xinhua, 22 December 2015, http://m.thepaper.cn/newsDetail_forward_1412138 (accessed on 30 January 2019). 
工人代表制) and "collective bargaining" (jiti tanpan 集体谈判) at its centre. We argue that this change in how some labour NGOs operate reflects the evolving needs of Chinese workers.

To make sense of this latest crackdown and put it into perspective, this paper is structured into four sections. In the first, we review the existing literature to trace the development of labour NGOs in China over the past two decades. In the second, we resort to the voices of the activists themselves to explain the reasons behind the shift of some NCOs towards collective bargaining, paying particular attention to the relationship between these organisations, the workers, and the "labour movement" as an imagined political entity. In the third, we outline the practice of collective bargaining as implemented by Chinese labour NGOs through the specific case study of the Lide mobilisation that played such an important role in media coverage of the latest crackdown. Finally, we will conclude with some general considerations regarding the future of labour NCOs and collective bargaining in China in an increasingly hostile political climate.

Both authors have extensive field experience with Chinese labour NGOs, From January 2009 to October 2015, the first author observed on a daily basis the implementation of eight international development cooperation projects aimed at promoting and protecting the rights of Chinese migrant workers. These were initiatives carried out in a collaboration between a foreign labour NCO and nine different local partners (three of which were different branches of the same organisation). Besides taking part in the project activities, he independently carried out dozens of semi-structured interviews with leaders and employees of labour NGOs. Between 2009 and 2018 this author interviewed a total of 65 people from 30 different NCOs, a dozen of whom were key informants with long-standing experience of labour activism who were interviewed more than once. The second author has also observed the implementation of similar international development projects since October 2015 in collaboration with seven local partners. He closely followed the Lide strike and the crackdown on labour NGOs in December 2015 and its aftermath.

We chose to focus on the Lide mobilisation as a case study because it featured prominently not only in materials produced by labour activists and NCOs back in 2014 and 2015 - in which it was hailed as a successful example of worker-led collective bargaining - but also in government propaganda about NCOs as subversive agents published in the wake of the crackdown of December 2015. In this sense, Lide can be considered representative of the interactions between workers and labour NCOs in the event of a successful collective mobilisation. At the same time, it is also a unique case in that it triggered the latest crackdown and was then re-appropriated by the Chinese authorities to boost their discourse against labour NCOs. The Lide case therefore has dual significance as a case of successful mobilisation and as a turning point for collective bargaining and labour NGOs.

The case study presented in this paper is based largely on extensive semistructured interviews jointly carried out by the two authors with NGO staff involved in the cases, worker representatives, as well as ordinary employees of the Lide factory. These materials have been complemented by secondary Chinese-language sources such as media reports and press releases prepared by the NGOs involved in the action. In particular, we conducted 17 in-depth interviews with worker representatives and other employees at Lide, three interviews with $\mathrm{NGO}$ activists involved in the mobilisation, as well as took extensive notes during an event organised by the NGO to celebrate the success of this struggle. We also made extensive use of a series of reports entitled "Lide Workers Rights Defence Updates" (LWRDU), released in real time on a Weibo account managed by staff of the Panyu Centre to record the course of the struggle. These documents were archived by the authors at the time and are now, unfortunately, no longer available online. Throughout the paper, all interviews with Lide workers have been anonymised through the use of pseudonyms. We also avoided explicitly attributing the interviews with labour activists, with the exception of Zeng Feiyang and Meng Han, whose roles have been covered extensively in the public domain.

\section{Setting the scene}

As Howell pointed out, "although the term ' $N G O$ ' conjures up the image of a legally registered entity with salaried professional staff, in China, with its tight registration regulations, [labour] NGO refers to a looser array of organizations that may or may not be legally registered, independent of government, and which may or may not have professional salaried staff and volunteers" (Howell 2015: 704-5). Such organisations first appeared in China in the mid-1990s, in the wake of the 1995 UN World Conference on Women, taking advantage of the opening of the Chinese government towards civil society and benefitting from an influx of foreign funding, in particular from Hong Kong (Chan 2013; Howell 2008; Pun and Chan 2004). Still, it was only under Hu Jintao and Wen Jiabao (2003-2012), when the Chinese Communist Party put renewed emphasis on labour rights under the umbrella of the official discourse on "harmonious society" (hexie shehui 和 谐社会), that labour NGOs gained traction in the country (Hui and Chan 2011). Nevertheless, given the political sensitivity of labour issues under the rule of a Communist Party that still claims to represent "the vanguard of the Chinese working class," up to this day such groups are rarely allowed to register as non-profit entities and usually end up with a commercial registration (gongshang zhuce 工商注册) or no registration at all. This - along with the precariousness of their funding - makes it almost impossible to quantify their exact number, with estimates varying from 40 to about 100 or more.

Traditionally, Chinese labour NGOs have focussed on three kinds of activities: a) the establishment of workers' centres, where they offer special interest classes, educational classes, and recreational activities, as well as legal consultation services and, in some cases, legal representation; b) outreach programs on labour rights; and c) social surveys and policy advocacy (Chan 2013; Xu 2013). This choice of upholding a strictly legalistic conception of legal rights has undergone severe scrutiny in the existing literature. While most scholars have maintained a positive assessment of the role that these organisations play in giving voice to otherwise powerless workers, pushing forward progressive policies, and fostering a new collective consciousness among Chinese workers, other academics have remained more sceptical. Among the earliest critics were Lee and Shen, who a decade ago singled out labour NGOs for their individualistic approach to labour rights, accusing them of being an "anti-solidarity machine" that was undermining the emergence of a collective consciousness among Chinese workers (Lee and Shen 2011). Equally controversial has been the issue of the relationship between labour NCOs and workers. Chris Chan noted that not all workers can benefit from the assistance of these organisations, as most NCOs rely on funding from overseas foundations that prefer to support the most vulnerable or exploited social groups and thus overlook the issues faced by ordinary employees (Chan 2013). Froissart observed that labour NCOs are "also working for the benefit of the Party-state, to which they adhere, min- 
imising social conflict and orienting reforms in a direction that can help the Party to maintain its power. While an integral part of the social movement of migrant workers, these organizations also delimit this social movement in their own way. These limitations are why some migrants question these NGOs' legitimacy to represent them" (Froissart 2005: 10). Finally, Franceschini argued that labour NCOs in China are undermined by a significant lack of "social capital," which can be seen in, among other things, the difficulties these organisations face when trying to gain the trust of workers who "believe that anybody who offers voluntarily to help them must have an ulterior motive" (Franceschini 2014: 485).

These criticisms have polarised the field of Chinese labour studies, with "optimist" and "pessimist" scholars accusing each other of wishful thinking and lack of long-term vision, respectively (Chan 2018b). Still, instead of trading blows on the basis of articles written several years apart, proponents of both perspectives should acknowledge that labour NGOs are not static entities, but subject to change according to social and political circumstances. As Anita Chan has recently observed, over the last three decades the relationship between workers and NGOs has changed from one of "workers' dependency on NGOs in an asymmetrical relationship to one of partnership" (Chan 2018a). In fact, in the past few years, a few labour NGOs - in our experience, no more than five - have started abandoning their traditional legalistic approach to promote a new strategy articulated around the concept of "collective bargaining," a reorientation prompted by the increasing collective mobilisation of workers in the form of street protests and strikes in southern China, and facilitated by support from a well-established Hong Kong-based labour NGO (Chan 2018a). Writing before the 2015 crackdown, Duan Yi, a prominent labour lawyer based in Shenzhen and a key partner to labour NGOs who played a fundamental role in the effort to promote collective bargaining in China, argued that Chinese labour NGOs were in the process of transforming from traditional "service-oriented" (fuwuxing 服务型) and "rights protection-oriented" (weiquanxing 维 权型) organisations to real "labour movement organisations" (gongyunxing zuzhi 工运型组织) (Duan 2015). It is impossible to quantify the exact number of collective disputes that in recent years have seen the involvement of labour NGOs, but academics provide ample evidence of NGO intervention in dozens of collective disputes since the early 2010s. For instance, Li and Liu (2016) investigated the unusual collaboration between the workplace union of a Walmart store in Changde, Hunan, and several labour NGOs in the struggle against some irregularities in severance payments when said shop was closed down. Another case study was presented by Chen, who followed the (attempted) involvement of Chinese labour NGOs in the 2014 protest by more than 40,000 workers in the Dongguan plant of Yue Yuen, a Taiwanese footwear company that had failed to pay social security for its employees (Chen 2015).

Some scholars have gone beyond an approach based on specific case studies in an attempt to build a comprehensive framework able to account for these changes. In a recent study, Chen and Yang have argued that the new "movement-oriented" labour NGOs promote a kind of "displaced unionism," whereas the term "unionism" is used to indicate "certain union-like roles these groups play, in contrast with many of their counterparts operating mainly as service providers, social workers, legal advisors, or advocates;" and "displaced" denotes the "actual social location of these groups and where they perform their roles" (Chen and Yang 2017: 159). In a more recent study based on the examination of the records of no less than 82 collective cases, Froissart offers an impressively detailed account of the role that labour
NGOs play in promoting "worker-led collective bargaining," helping workers design strategies to engage with employers, trade unions, and local authorities so that they can "[exercise] their rights before they are granted and by putting pressure on authorities to act as real authorities rather than representatives of a rogue state" (Froissart 2018: 13). In line with these recent studies, we now turn to discussing both the discourse and practice of collective bargaining as proposed by activists in Chinese labour NGOs.

\section{Collective bargaining and the "labour movement"}

Since the mid-1990s, the Chinese labour law has allowed workers the possibility of stipulating collective contracts (jiti hetong 集体合同) with their employers. Still, from the outset the Chinese authorities have systematically undermined this institution to ensure that no communion of interests emerged among the workers during the negotiation process. First, the confrontational nature of "collective bargaining" (jiti tanpan 集体谈判) - which implies a conflict of interests between employers and employees - was watered down in a process of "collective negotiation" (jiti xieshang 集体协商) based on the assumption of a substantial unity of interests between company and workers (Brown 2006). Second, the coverage of collective agreements was generally limited to the company level, with only the 2008 Labour Contract Law granting workers the right to sign collective contracts at the industry or local level (Wang and Wang 2002). Third, the issue of the right to strike - vital to collective bargaining - has deliberately been kept in a grey area (Chang and Cooke 2015). Finally, the official union, which has been given a fundamental role in representing workers in collective negotiations, has approached the issue in a formalistic way, simply setting quotas of collective contracts to be reached by local unions (Liu and Kuruvilla 2017). In light of these shortcomings, to this day most collective contracts in China simply reaffirm minimum standards already provided by law.

Still, in recent years scholars have highlighted the existence of different practices of collective bargaining in China. In particular, Chan and Hui have highlighted a substantial difference between "Party-State-led collective bargaining" and "collective bargaining by riots" (Chan and Hui 2014). These two strategies have divergent goals: the former is an effort led by the Partystate to pre-emptively institutionalise wage bargaining, primarily aimed at containing labour conflict; the latter emerges only after workers stage collective actions and demand direct negotiation with management, and thus contributes to building workers' collective power, confidence, and capacity. In the early 2000s, there have also been innovative experiments with tripartite sectoral bargaining as part of top-down ACFTU reforms (Friedman 2014). For instance, Wen and Lin (2015) analysed the development of sectoral bargaining in one county in Wenling, Zhejiang Province. There, under pressure from workers' collective actions, a group of factory owners formed an industry association in an attempt to standardise piece rates to avoid competition on wages. In the meantime, as a result of intervention by the local branch of the official trade union, workers formed a sectoral union and elected their own representatives to negotiate with the industry association. This provided a potential alternative to enterprise-level bargaining by strengthening the bargaining power of the workers. Despite early successes, however, the subordination of the sectoral union to the Party-state eliminated it as a viable model of collective bargaining.

Most importantly, as Froissart has effectively shown, in recent years labour NGOs have enabled the emergence in China of authentic "worker-led col- 
lective bargaining" in which workers are able to put forward demands that go beyond the basic legal minimum (Froissart 2018). In a context of such systematic disempowerment of collective contracts and negotiations, why did some labour NGOs decide to shift their focus to collective disputes and collective bargaining in the first place? Our interviews highlight two main reasons for this "readjustment" (tiaozheng 调整). First, NGO leaders in "movement-oriented" organisations expressed a notable disenchantment with a legalistic strategy focussed on individual cases, seen as ineffective in improving labour conditions and bringing forward any political change on a larger scale. In the words of one of them:

Before we used to focus on the usual legal training, legal aid, and cultural and recreational activities, but after doing this for many years we felt that the problems faced by the Chinese labour movement go beyond the realm of the law. It is not that providing workers with legal counsel and legal aid can solve their problems. It is not like that. What do workers lack in China? They lack solidarity and organisation. If they don't have organisation, it is very difficult to change their position of weakness. For instance, if you use the law, you can only protect the most basic rights that you have, such as getting the minimum wage. Some things cannot be solved through the law. ${ }^{(4)}$

Second, facing new collective threats that have emerged in force in recent years due to the aging of the workforce and the slowing down of the economy in China - such as those related to missed payments to social security funds and factory relocations - the needs of Chinese workers themselves appeared to have shifted. Constrained by these changing demands, some NGO leaders felt that they had no choice but to adapt, because if they failed to do so they faced two fundamental risks: "One, to be incorporated [by the state]; two, to have an increasingly small market." "(5) The experience of one labour NGO established in 2012 with the aim of carrying out cultural and recreational activities for female migrant workers is particularly illuminating in this regard. As one of the leaders, herself a former migrant worker, recounted:

At the end of 2012, many controversies between labour and capital arose in the factories around us, and these female workers came to our centre to ask for information. (...) During the winter, we organised a meeting during which we asked them to vote on what kind of activities best fit their interests. They chose training in law, collective bargaining, and communication techniques. Their choices were completely different from what we expected! On this basis, since the end of 2012, we have rearranged our work to start dealing with the rights of female workers and with collective bargaining. ${ }^{(6)}$

Collective bargaining seemed exactly the right strategy to both bring forward positive and widespread changes in a relatively short time - compared to previous strategies focussed on community-building and individual legal assistance, which would take a long time and many resources - and address the new collective needs of the workers. The need to foster a closer relationship with the workers was indeed crucial in shaping the agenda and priorities of "movement-oriented" NGOs. Still, while recognising the need for such a strategic change, on a discursive level most of our interviewees in these NCOs chose to de-emphasise the link between collective bargaining and the "labour movement" (gongyun 工运) as a political imaginary, objecting in varying degrees to their organisations being labelled "labour movement organisations," a term coined by lawyer Duan Yi and his supporters. There is no question that, as Froissart pointed out, these organisations are "an integral part of the worker movement," considering that they have both sociological and operational legitimacy as former workers themselves, and they do not act on behalf of the workers, but rather pursue workers' psychological and practical empowerment (Froissart 2018: 32-3). Nevertheless, in our interviews, leading activists in these NCOs tried to put some discursive distance between themselves and the working class. One of these activists described the relationship between NGOs and workers in rather paternalistic terms:

Through our efforts we also hope to improve the system (...) but today our workers don't have these kinds of demands yet. Normally, a labour movement should have workers at its centre, but at this moment workers still don't have this kind of awareness or mobilisation capacity. In the past, the work was done by NGOs or by movement-oriented NGOs, but now the situation has evolved and workers should be the centre. Maybe now we will just walk in front of them, providing them with support and encouragement. ${ }^{(7)}$

Some challenged the identification of the narrative of "labour movement" with an agenda of collective bargaining that they perceived as too narrow:

What's a labour movement? A labour movement consists of more than collective bargaining. I believe that a labour movement is something sacred, something huge. It is not only about organising a trade union inside a factory to challenge the internal system; we have to oppose the government's unfair treatment and oppression, do something bigger. You cannot use the term labour movement so casually. That is why I don't agree with this idea and even oppose it. ${ }^{(8)}$

Others were wary of the political implications of applying the "labour movement" label in a political system in which the ruling party still presents itself as the "vanguard of the Chinese working class:"

I think it would be more appropriate to define us as "comprehensive organisations" (zonghexing 综合型). Why? Because our organisation carries out service work, rights-protection work, and even some work with strikes simultaneously. (...) Sure, you can also talk about a labour movement, the expression is not bad, but in my opinion it is not complete, it doesn't cover all facets. Moreover, this expression easily attracts the attention of the government. If you talk about a labour movement, the Party, which established itself exactly through the labour movement (...) gets alarmed. Why? Because this is the way in which they came to power. ${ }^{(9)}$

Undoubtedly, discourse matters. In 2014 and 2015, in spite of such private expressions of caution, in the public arena Chinese labour NGOs were often unquestioningly identified with a politically-charged, loosely defined "labour

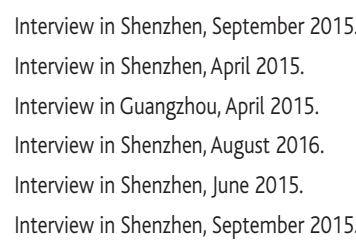


movement," and scholars, journalists, and some activists themselves went so far as to portray these organisations as full-fledged independent unions. And indeed, in going beyond a merely legalistic approach to assist workers in choosing their own representatives to bargain collectively with their employers, labour NGOs were posing a fundamental challenge to the All-China Federation of Trade Unions (ACFTU), the only trade union legally allowed in China. Already in February 2015, LiYufu, vice-president of the ACFTU, had sounded the alarm against these practices of labour NGOs. ${ }^{(10)}$ Noting that "the trends in the field of industrial relations are complex and intricate, and labour contradictions have already entered a phase of intensification and multiplication," Li denounced "interference by hostile foreign forces getting stronger, in a futile attempt to use industrial relations to break through." According to Li, these forces "resort to some illegal 'rights protection' labour organisations and individuals to vie with the unions for workers, and in so doing they break the solidarity of the working class and the unity of the unions." In light of this, it did not come as a surprise when, in December 2015, Chinese state media decided to launch their attack with blaring headlines that openly mocked Zeng Feiyang for "posing as a star of the Chinese labour movement." More surprising was how these outlets invariably decided to frame their assault around the mobilisation of the Lide workers, a landmark achievement not only for Zeng Feiyang, but for Chinese labour NGOs as a whole.

\section{The practice of collective bargaining: The case of Lide}

The mobilisation of workers at Lide is an important case study of successful "worker-led collective bargaining" triggered by the intervention of labour NGOs. In 2014, the Guangzhou Lide Footwear Company, which at that time employed more than 2,000 workers and produced leather shoes for global brands, began planning to relocate its factory and laying off part of its workforce. In August 2014, as management started to transfer production equipment to the new facility, a small group of workers turned to the Panyu Centre and asked for their assistance, to which the organisation leaders agreed (LWRDU 1, 5 December 2014). There was a specific reason why the Lide workers turned to this organisation. Like other labour NGOs established in the late 1990s, in the first decade of its existence the Centre had focussed on assisting workers on individual legal cases and conducting labour rights training. In 2011, however, the group began considering a shift in its focus and strategy. As Zeng Feiyang explained to us in 2015: "When strikes happened, people only knew about the strike from the outside, and no social organisation was concerned about, responded to, or helped amplify their voice." Aiming to fill this role, the Panyu Centre reoriented their work toward supporting the collective actions of migrant workers.

The Panyu Centre was among the earliest organisations to explore collective bargaining and to make a serious attempt to develop worker representative structures for the purpose of mobilisation and bargaining. Zeng and his colleagues believed in the importance of strengthening the collective actions of the workers by providing them with sound legal advice and practical support. However, in deciding whether to support a particular case, they had to assess whether the conditions were suitable for collective bargaining. For instance, according to Meng Han, they did not consider protests over factory relocation an ideal situation for collective bargaining, and in such cases they usually would advise workers to turn to official complaint or litigation. ${ }^{(11)}$ As Zeng Feiyang explained:
Cases such as factory relocation are not suitable for bargaining or for our intervention. We would recommend that they directly register a complaint with the Labour Bureau (...) what we are after is not one-off, but sustainable bargaining, not the kind that workers leave after one bargaining. Certainly this has some benefit to workers' rights defence, but we think it is not of great value for our exploration of collective bargaining as a system. ${ }^{(12)}$

This shows that the Panyu Centre - like other similar "movement-oriented" NGOs - was committed to making long-term change through collective bargaining rather than reaping short-term gains for workers. In this sense, it was not an ideal strategic choice for them to assist workers in a dispute over factory relocation, but in the case of Lide, they saw the potential to experiment with their model. Tang, a veteran worker who had worked at Lide for more than 14 years, was among the first group of workers who approached the Panyu Centre. In an interview, she described to us how little she and her co-workers knew about their legal entitlement to compensation and about the procedures to follow to claim it. ${ }^{(13)}$ Another worker in the group surnamed Zeng similarly recounted how little they knew about the labour laws: "At the beginning, I was ignorant, really ignorant, and lacking in legal knowledge." (14) Not surprisingly, neither had any prior experience of struggle, and both were at a loss about what to do next. However, the Lide workers soon began to show potential for mass mobilisation.

\section{First contacts between NGO and workers}

In August 2014, the Panyu Centre sent several of its staff as advisors to meet with the workers. While only a moderate turnout was expected, the meetings attracted hundreds of Lide employees keen on asking about their legal rights. This deepened the commitment of the Panyu Centre advisors to the case. Meng Han, one of these advisors, explained the role that he and his colleagues played at this early stage:

When we first made contact with them, we helped them to create organisation, improved the structure of worker organisation, clarified their demands, and told them what their rights were (...) During this process, we also needed to be cautious about the risks from the government. We had many internal meetings (...) In general, in the case of Lide our NGO intervened from the inside, analysed each step, and did some strategising. How do we take this step? How to guide workers? In some respects, some workers were easily divided and atomised (fenhua wajie 分化瓦解), or lured and threatened by the authorities. We needed to tell them how to rationally (lixing 理性) think about these problems. (...) This whole process needed organising (zuzhihua 组织化). ${ }^{(15)}$

10. “全国总工会党组书记：境外敌对势力通过“维权”与工会争夺职工” (Quangguo zonggonghui dangzu shuji: Jingwai didui shili tongguo "weiquan" yu gonghui zhengduo zhigong, The secretary of the Party group of the ACFTU: Hostile foreign forces vie for workers with the trade union through "rights protection"), 瞭望周 刊 Liaowang Zhoukan, 28 February 2015, http://www.guancha.cn/society/2015_02_28_310576_1.shtml (accessed on 30 January 2019).

11. Interview in Guangzhou, July 2015.

12. Interview in Guangzhou, July 2015.

13. Interview in Guangzhou, September 2015.

14. Interview in Guangzhou, September 2015.

15. Interview in Guangzhou, July 2015. 
In doing so, the advisors not only brought legal knowledge and organising experience to the workers, but also provided them with an existing model of worker representation and collective bargaining that they had developed through their involvement in several previous cases. In the following months, the mobilisation progressed apace. Between September and November 2014, under the guidance of advisors from the Panyu Centre, Lide workers held multiple staff meetings and elected their worker representatives from each department to gain the trust of workers across the factory. A leading worker representative described the sense of empowerment workers felt after these meetings:

In the past, we would not dare to talk back to the group leader even when he was cursing. But after the first meeting, everyone was more aware of their rights, and knew how to protect themselves. Later on, [we were] not even afraid of the section manager (kezhang科长), and could confront him. Rights defence is really important. [We] learned a lot. ${ }^{(16)}$

A core group of 13 worker representatives who acted as organisers and negotiators was thus formed to represent the interests of workers in the process of bargaining. While in labour mobilisations in China worker leaders usually emerge organically without any intervention from labour NGOs or any other external groups (Leung 2015), in this specific case it is clear that NGO advisors facilitated and possibly accelerated the formation of this worker representative structure.

\section{Escalation of the conflict}

It was at this point that the management at Lide caused an escalation in the mobilisation. Workers told us that in December 2014 they became alarmed and angry when managers asked them to sign a new contract that set their first date of employment in 2008, when in fact a majority of them had been employed at the factory since the late 1990s. Moreover, this contract only included the base wage of RMB 1,550, which workers suspected would be used as the basis for calculating the amount of compensation. In light of this, the workers came to believe that the company would refuse to pay the full compensation for contract termination mandated by law. They also began to inquire about housing funds and social insurance, two issues of particular importance to workers in their forties and fifties who were nearing retirement age. When some workers refused to sign the fake contract, management threatened them with immediate dismissal.

This development pushed workers to adopt more extreme measures, with the worker representative structure already in place allowing them to provide a fast response. On 6 December 2014, a group of worker representatives from one production department initiated a work stoppage that sparked a factory-wide strike (LWRDU 1: 5 December 2014). While not explicitly encouraging or leading the mobilisation, the Panyu Centre advisors expressed strong support for the decision of the workers to go on strike, arguing that this was central to building their power. ${ }^{(17)}$

\section{Steering the mobilisation}

Meng Han explained how the advisors guided the workers in the collective bargaining process:

They went on strike three times, and three times they returned to work. In this process, we provided them with suggestions on specific demands that they could bring up for the purpose of collective bargaining, in accordance with the requests of the workers. Collective bargaining is a mutual process, a process of advancing and retreating, which requires some techniques. In the case of Lide, we basically used the accumulated experience of the Panyu Centre, and also fully discussed and evaluated some new problems in order to make strategic decisions. ${ }^{(18)}$

The importance of NGO involvement in shaping the bargaining process is highlighted by a leading worker representative, who recalled that on the night of the strike, the NGO advisors wrote a request for collective bargaining on behalf of the workers, listing 13 conditions and demands. ${ }^{(19)}$ The proposal specifically emphasised that in accordance with the Labour Contract Law, workers had selected their own representatives and demanded the following from the company: a) no retaliation against workers and worker representatives; b) a written response regarding the rumours of impending relocation, and, in case they were true, an agreement to negotiate a settlement with the workers; $c$ ) the payment of social insurance and housing fund contributions since the date of employment; d) full payment of overtime and high temperature allowance; e) paid annual leave and paid maternity leave; f) at least one day off per week; g) occupational health check-ups for workers; and $\mathrm{h}$ ) the stipulation of permanent contracts with eligible workers (LWRDU 4: 4 February 2014).

The proposal reflected the Panyu Centre's particular approach to collective bargaining. This consisted of placing the demands of the workers firmly within the perimeters of the labour law, while at the same time aiming at forcing management to recognise the workers' right to bargain collectively with the company. However, although the demands that NGO advisors put forward in the Lide case were comprehensive, they were also curiously illsuited to a relocation dispute - which explains the original reluctance of the NGO leaders to take on a relocation case - as the goal of many Lide workers was to claim layoff compensation and to have their social insurance contributions paid, rather than to demand any longer-term benefits. In light of this, the focus of the demands in subsequent negotiations remained on compensation and on back payment of social insurance and housing funds.

\section{Conflicts between workers and the NGO}

NGO advisors played an important role in steering the mobilisation of the Lide workers in other ways as well. Later on in the struggle, when concern arose that worker representatives had failed to perform their role, the Panyu Centre took steps to discipline them. In late March and early April 2015, five of the worker representatives held separate and secretive negotiations with the local government, and did not fully disclose the results until later, to the surprise of other worker representatives. They were suspected of being either bought off by management or co-opted by the authorities, although no evidence was produced and details remained murky. The NGO advisors helped initiate their recall and subsequent demotion, and held a new election to replace them. Significantly, this incident featured prominently in the media campaign against Zeng Feiyang and his colleagues, played up as evidence of how the Panyu Centre manipulated workers and punished those who did not follow their lead.

16. Interview in Guangzhou, September 2015

17. Interview in Guangzhou, July 2015

18. Interview in Guangzhou, July 2015.

19. Interview in Guangzhou, September 2015. 
If anything, this shows how the relationship between labour NGOs and workers is indeed multi-faceted. While emphasising that it was the workers who wanted to bargain collectively, Meng Han explained that after the first strike, it was the NGO advisors who insisted that Lide workers resort to this strategy. In his opinion, the relationship between the two sides was not paternalistic, but "complementary" (hubu 互补):

We taught them the legal knowledge and rules of collective bargaining to enable them to use collective bargaining to fight for their rights and interests. It was not really a teacher-student relationship. I know a bit more, and I am also a worker. I only thought of ways to help them. The relationship is one of mutual help. (20)

However, the relationship was also more complex than that. Asked if the two sides had conflicting ideas, Meng conceded:

There were certainly differences. Since worker representatives didn't have a theory of collective bargaining, we needed to slowly introduce them to the knowledge and concepts we knew, allowing them to slowly digest this information. (...) The difference is that their understanding was not sufficient. Let me use an example: looking back at the five worker representatives in the early stage, they hoped they could use a soft (rouxing 柔性) approach to negotiating with the boss, saying the same things over and over again and begging, asking the boss to agree to specific individual demands or agreements. (...) But we were different. We knew that the more you used this approach, the tougher the management would become... Collective bargaining has to be equal, and only by having power you can negotiate. ${ }^{(21)}$

\section{Facing the official union and local authorities}

In substance, NGO advisors pursued a strategy that combined strengthening the confidence and organisation of the workers with channelling their grievances into collective bargaining. At that point, the local government also intervened not only by sending in the police, but also by trying to compel the management at Lide to reach a settlement with workers. After a prolonged struggle that lasted from September 2014 to April 2015 - including three separate strikes that saw the factory occupied for a total of 11 days, and four rounds of bargaining - the Lide workers eventually succeeded in securing their core demands on social insurance contributions, factory closure compensation, and the housing fund. In the end, while few Lide workers knew about labour NGOs prior to the struggle, they were left with a positive impression of the Panyu Centre. Asked about its importance in the Lide case, a leading worker leader believed that:

They played the most important role. It is because of their leadership that we have today's (result) (...) having experienced strike after strike, we became best friends (...) I think we workers especially need people like them now. ${ }^{(22)}$

Another worker representative said that they would turn to the Panyu Centre if they need help again, because without them they would not have won. (23)

These positive impressions of the Panyu Centre sharply contrasted with the negative perception of the official trade union - a situation that shows how the concerns expressed by ACFTU leaders about labour NGOs vying with the union for workers had some grounds in reality. In fact, shortly after the first strike in December 2014, the deputy chairperson of the Panyu district union led a six-person delegation to Lide and held a consultation with a few worker representatives. The union inquired about the reasons for the strike, the demands of the workers, and the selection process of workers representatives. It recommended "rational rights defence" (lixing weiquan 理性维权), namely not interrupting production, and making all necessary compromises. The delegation reiterated that the union represents workers' interests in accordance with the law, and supports workers to defend their rights in accordance with the law (LWRDU Update 6: 4 February 2014). However, worker representatives rejected the role of the union in their negotiation, arguing that the negotiation should be exclusively between workers and management (LWRDU Update 6: 4 February 2015). Failing to gain the confidence of the workers, the union was not party to most of the subsequent negotiations. After the strikes, when asked if the union could protect workers' rights, one worker representative simply replied: "I don't understand. I never heard of them, nor do I know what they do. I absolutely do not know." (24) Another Lide worker said: "Union... I did not see any union... I never heard of it. Why would a factory have a union?" (25) A Panyu Centre staff member observed:

As for the union, in this case they did not intervene. Workers did not trust the union, and workers refused to have the union intervene. This is what we advocated at the beginning: labour-capital issues should be resolved by labour and capital. In their subconscious, the workers saw the union as a third party. For this reason, they felt that the union should not intervene. But the union was at the scene [of the strike]. Because workers did not trust the union, they had no way to intervene. When the union was present at the negotiation, workers refused to negotiate. (26)

It may seem curious that a labour NGO, which had been instrumental in facilitating collective bargaining, insisted on direct negotiation between the worker representatives and management. But once the core group of worker representatives was formed, NGO advisors did not need to be at the negotiating table: the goal was not for the NGO to directly represent workers, but rather to facilitate the formation of workers' own workplace organisation. In fact, while no labour NGO has publicly advocated for or actively organised independent unions, cases like the Lide struggle show that organisations such as the Panyu Centre were creating parallel structures in the form of the worker representative system. According to our interviews, although in many cases Chinese labour NGOs still encourage workers to send petitions to the local union branch to demand their help, they do so knowing full well that this will result in the union demonstrating its inefficiency and the workers becoming increasingly aware of the limitation of the system. Whether they adopt a confrontational attitude towards the union or not, this strategy has only one effect: that of excluding ACFTU branches

\footnotetext{
20. Interview in Guangzhou, July 2015

21. Interview in Guangzhou, July 2015.

22. Interview in Guangzhou, September 2015.

23. Interview in Guangzhou, September 2015.

24. Interview in Guangzhou, September 2015.

25. Interview in Guangzhou, September 2015.

26. Interview in Guangzhou, July 2015.
} 
from collective bargaining, and thereby leading worker organisations to eventually supersede and displace the role of the unions.

In contrast, activists still believed that the government has an important role to play in forcing management into collective bargaining with workers, a role that the local authorities fulfilled in the Lide case. For example, Meng Han thought that it would have been useful to work with the government - as long as the government was willing - because such cooperation would quicken the dispute resolution process and reduce risk. (27) A worker representative surnamed Zhang believed that the government was helpful during the third strike, and in fact she and other workers sought direct help from the government when the strike proved inadequate to force management to concede. ${ }^{(28)}$ An anonymous staff member at the Panyu Centre believed that the government played a positive role in creating the structure for labour-capital negotiation, but its decision to send in the police over concerns for social stability was excessive. ${ }^{(29)}$ In the case of Lide, the government stepped in to fill the gap left by the union, but it sought to discipline both workers and management, coercing them into bargaining and away from collective action.

\section{Celebrations}

In May 2015, the Panyu Centre organised a meeting to celebrate the victory at Lide, using it to share and spread the lessons learned during the struggle. At the meeting, which was also attended by labour scholars and practitioners, NGO staff and Lide worker representatives spoke of their organising and negotiating experiences, emphasising how the Lide case provided a successful blueprint for worker representation and collective bargaining (LWRDU 27: 21 May 2015). Indeed, for the Panyu Centre and other "movement-oriented" NGOs, Lide represented not simply a successful case of labour mobilisation, but also a proof of the effectiveness of their particular strategy. As a Panyu Centre staff member explained to us: "This case was especially exemplary, and its impact was considerable. When we deal with other cases in the future, this would become a flag for positive promotion: If they have done this, you certainly can." (30)

\section{Conclusion}

In this paper, we have highlighted that over the past few years a few Chinese labour NGOs have gone beyond their traditional approach based on community building and atomised legal consultation to actively promote a new industrial relations framework built around the practices of worker representation and collective bargaining. This shift has been determined by both the disgruntlement of labour activists with the limitations of their previous work and the shifting demands of the workers. While this change has entailed a dramatic reconfiguration of the relationship between NGOs and workers, we have shown that the relations between labour activists and the broader labour movement as an imagined collective entity remain highly sensitive and mixed. Discursively, NGO leaders walk a fine line between portraying themselves as the vanguard of the Chinese labour movement, while keeping some distance to avoid political repercussions. Practically, as we have seen in the case of the successful struggle at Lide, the relationship between activists and workers remains fraught with challenges, contrary to the easy narratives that see NGOs alternatively manipulating the workers or merely advising - if not leading - them. On a broader political level, in the absence of political support from the Chinese state or the ACFTU, labour
NGOs have been driving the institutionalisation of collective bargaining from below, a clear departure from the top-down "collective consultation" model promoted by the Chinese authorities with the assistance of the ACFTU. This attempt, if successful, would have changed the legal regime governing industrial relations, leading to a further marginalisation of the ACFTU. For this reason, this shift in NCO strategies was perceived as a political threat by both union and Party, a situation that most likely determined the decision of the authorities to launch their latest crackdown on "movement-oriented" organisations.

Since, as Howell and Pringle have noted (2018), there is no such a thing as "unchanging authoritarianism," these developments should also be put in the broader context of the shifting relations between Party-state, workers, and civil society. As we have seen, labour NGOs first appeared in China in the mid-1990s because the Chinese Communist Party was looking for new strategies to manage the rise of social unrest spurred by the side effects of economic development, in particular for migrant workers. Acting as a safety valve for worker unrest, labour NGOs were able to survive by continuously "re-negotiating" with the authorities the terms of their existence and the boundaries of what was permissible, a dynamic that Jude Howell (2012, 2015) describes well. For a few years at the beginning of this decade, collective bargaining appeared to fall into the realm of possibility, and some labour NGOs were eager to take advantage of this opening to expand their work in new directions. The Panyu Centre - which was established in the late 1990s - is emblematic of this trajectory. Still, under Xi Jinping, the Party-state, prompted by fear of losing control over labour NGOs, decided to reclaim the space it had previously granted them. This was also a consequence of the building, year after year since the early Hu-Wen administration, of a pervasive architecture of "stability maintenance" (weiwen 维稳), as the ad hoc solutions prescribed by policy-makers over the years regularly failed and the Party-state had to scramble for new social compromises (Biddulph 2015). While the latest crackdown has led to an almost complete annihilation of the most active labour NGOs involved in both rights protection and collective bargaining, it is important to bear in mind that this has not removed the necessity for the Party-state to negotiate new processes of conflict resolution in the field of industrial relations. For the time being, the Chinese authorities seem to be relying mostly on violence and coercion as was apparent in the crackdown on workers, their Maoist supporters, and (once again) labour NGOs at Shenzhen Jasic Technology Ltd. in summer 2018 after workers demanded unionisation (Zhang 2018) - but this strategy is far from sustainable and can easily lead to an escalation of conflicts.

In such dire circumstances, what space is there today in China for labour NGOs to get involved in collective bargaining? As Froissart has pointed out, "the limit of [worker-led] collective bargaining (...) are that they remain subject to the tolerance of and self-perceived interests of trade unions and local authorities, which is why they remain isolated experiments circumscribed at the enterprise level, with no immediate prospect of becoming systematized and institutionalized" (2018: 13). What the Lide case shows is a strategic attempt by a labour NGO to develop a collective bargaining model that excludes trade unions and, in part, even local authorities, with a well-defined goal to systematise and institutionalise the practice. Unfortunately, in today's

\footnotetext{
27. Interview in Guangzhou, July 2015.

28. Interview in Guangzhou, September 2015.

29. Interview in Guangzhou, July 2015

30. Interview in Guangzhou, July 2015.
} 
China tolerance for such efforts is increasingly hard to come by, and collective mobilisations such as the Lide case now belong to the past. Most labour NCOs that are still active today have given up any pretence of conducting rights protection activities and have gone back to being simple serviceproviders on behalf of the local state, focussing on recreational initiatives and welfare provision. Others have simply closed down, with members of their staff reinventing themselves as barefoot lawyers (where still allowed), or starting some new profit-oriented venture. While some labour organisations are still taking on collective cases and promoting collective bargaining, they do so in a restrained manner, at least compared to what used to be the practice before the latest crackdown. Franceschini and Nesossi (2018) have highlighted how those organisations that still promote collective bargaining carry out their activities with a heightened sense of danger. They are not only more careful in screening their cases, but also repeatedly warn workers about the dangers of resorting to this kind of strategy, and avoid disruptive events in favour of training in locations far away from the workplace. However, the coordinated arrest and incrimination of five labour NGO activists in January 2019 for "gathering a crowd to disturb public order" (juzhong raoluan shehui zhixu zui 聚众扰乱社会秩序罪) could very well be related to their previous involvement, in various capacities, in collective mobilisations. If this is the case, it will send a further signal that the Chinese authorities are unwilling to tolerate even a greatly toned-down involvement in collective bargaining.

\section{References}

BIDDULPH, Sarah. 2015. The Stability Imperative: Human Rights and Law in China. Vancouver: University of British Columbia Press.

BROWN, Ronald. 2006. "China's Collective Contracts Provisions: Can Collective Negotiations Embody Collective Bargaining?" Duke Journal of Comparative \& International Law 16(1): 35-78.

CHAN, Anita. 2018a. "The Relationship between Labour NGOs and Chinese Workers in an Authoritarian Regime." Global Labour Journal 9(1): 1-18.

CHAN, Chris King-chi. 2018b. "The Future of Labour NGOs: A Response to Two Mindsets." Hong Kong Confederation of Trade Unions. http://en.hkctu.org.hk/mainland-china/position-and-analysis/the-futureof-labour-ngos-a-response-to-two-mindsets (accessed on 30 January 2019).

CHAN, Chris King-chi. 2013. "Community-Based Organizations for Migrant Workers' Rights: The Emergence of Labour NGOs in China." Community Development Journal 48(1): 6-22.

CHANG, Kai, and Fang LEE COOKE. 2015. "Legislating the Right to Strike in China: Historical Developments and Perspectives." Journal of Industrial Relations 57(3): 440-55.

CHAN, Chris King-chi, and Elaine Sio-ieng HUI. 2014. "The Development of Collective Bargaining in China: From 'Collective Bargaining by Riot' to 'Party-state Led Wage Bargaining'." The China Quarterly 217: 221-42.

CHEN, Feng, and Xuehui YANG. 2017. "Movement-oriented Labour NGOs in South China: Exit with Voice and Displaced Unionism." China Information 31(1): 155-75.

CHEN, Jay 陳志柔. 2015. "中国威权政体下的集体抗议：台资厂大罢工的 案例分析" (Zhongguo weiquan zhengti xia de jiti kangyi: taizichang dabagong de anlifenxi, Protest mobilisation in an authoritarian regime: $A$ wildcat strike in Southern China). 台湾社会学 Taiwan Shehuixue 30: 1-53.

DUAN, Yi 段毅. 2015. “工运型劳工NGO的前景与挑战” (Gongyunxing laogong NGO de qianjing yu tiaozhan, Prospects and challenges for labour NGOs of the labour movement type). 公民 Gongmin, 20 May 2015. https://cmcn.org/archives/17927 (accessed on 30 January 2019).
This represents a huge change compared to the openness and boldness with which labour NGOs used to get involved in high-profile collective cases, including the Lide mobilisation. And yet, although this is undoubtedly a retreat for labour NCOs, the experience of those "movement-oriented" organisations should not be discounted as a short-lived and inconsequential experiment conducted by a few brave activists. Cases such as the Lide mobilisation have left behind an important legacy for both Chinese workers and labour activists to draw on, providing them not only with much-needed know-how in how to mobilise, but also in what mistakes to avoid. More importantly, they have made Chinese workers understand that it is possible for them to successfully mobilise, and that organisation is key to achieving their goals.

\section{Ivan Franceschini is a Postdoctoral Fellow at the Department of Political and Social Change, Coral Bell School of Asia Pacific Affairs, The Australian National University, and Co-editor-in-Chief of the open access quarterly Made in China journal (ivan.franceschini@anu.edu.au).}

I Kevin Lin is the China Program Officer at the International Labor Rights Forum in Washington, DC.

Manuscript received on 14 May 2018. Accepted on 25 January 2019.

FRANCESCHINI, Ivan. 2014. "Labour NGOs in China: A Real Force for Political Change?" The China Quarterly 218: 474-92.

FRANCESCHINI, Ivan, and Elisa NESOSSI. 2018. "State Repression of Chinese Labor NGOs: A Chilling Effect?" The China Journal 80: 111-29.

FRANCESCHINI, Ivan, and Elisa NESOSSI. 2017. "The Foreign NGOs Management Law: A Compendium." In Ivan Franceschini, Kevin Lin, and Nicholas Loubere (eds.), Made in China Yearbook 2016: Disturbances in Heaven. Canberra: ANU Press. 60-7.

FRIEDMAN, Eli. 2014. Insurgency Trap: Labor Politics in Postsocialist China. Ithaca: Cornell University Press.

FROISSART, Chloé. 2018. "Negotiating Authoritarianism and Its Limits: Worker-led Collective Bargaining in Guangdong Province." China Information 32(1): 23-45.

FROISSART, Chloé. 2005. "The Rise of Social Movements among Migrant Workers: Uncertain Strivings for Autonomy." China Perspectives 61: 30-40.

HOWELL, Jude. 2015. "Shall We Dance? Welfarist Incorporation and the Politics of State-Labour NGO Relation." The China Quarterly 223: 702-23.

HOWELL, Jude. 2012. "Civil Society, Corporatism and Capitalism in China." Journal of Comparative Asian Development 11(2): 271-97.

HOWELL, Jude. 2008. "Civil Society and Migrants in China." In Rachel Murphy (ed.), Migrant Labour and Social Development in Contemporary China. London: Routledge. 171-94.

HOWELL, Jude, and Tim PRINGLE. 2018. "Shades of Authoritarianism and State-Labour Relations in China." British Journal of Industrial Relations, online first on 9 October, https://doi.org/10.1111/bjir.12436.

HUI, Elaine Sio-leng, and Chris King-chi CHAN. 2011. "The 'Harmonious Society' as a Hegemonic Project: Labour Conflicts and Changing Labour Policies in China." Labour, Capital and Society 44(2): 154-83.

LEE, Ching Kwan, and Shen YUAN. 2011. "The Anti-Solidarity Machine? Labor Nongovernmental Organizations in China." In Sarosh Kuruvilla, Ching Kwan Lee, and Mary E. Gallagher (eds.), From Iron Rice Bowl to Informal- 
ization. Ithaca and London: Cornell University Press. 173-87.

LEUNG, Parry. 2015. Labor Activists and the New Working Class in China: Strike Leaders' Struggles. New York: Palgrave Macmillan.

LI, Chunyun, and Mingwei LIU. 2016. "A Pathway to a Vital Labour Movement in China? A Case Study of a Union-Led Protest against Walmart." In Mingwei Liu and Chris Smith (eds.), China at Work: A Labour Process Perspective on the Transformation of Work and Employment in China. London: Palgrave. 281-311.

LIU, Mingwei, and Sarosh KURUVILLA. 2017. "The State, the Unions, and Collective Bargaining in China:The Good, the Bad, and the Ugly." Comparative Labor Law and Policy Journal 38(2): 187-210.

Lide Workers Rights Defense Update (LWRDU), series of briefs about the Lide struggle released by the Panyu Migrant Workers Centre starting on 5 December 2014 and no longer available online.
PUN, Ngai, and Wai Ling CHAN. 2004. "Community Based Labour Organizing." International Union Rights 11(4): 10-1.

WANG, Quanxing 王全兴, and Min WANG 汪敏. 2002. “工会法2001年修 改的成功与不足" (Gonghuifa 2001 nian xiugai de chenggong yu buzu, Successes and shortcomings of the 2001 amendment to the Trade Unions Law). 华东法律评论 Huadong Falü Pinglun 1: 114-38.

WEN, Xiaoyi, and Kevin LIN. 2015. "Restructuring China's State Corporatist Industrial Relations System:The Wenling experience." Journal of Contemporary China 24(94): 665-83.

XU, Yi. 2013. "Labor Non-governmental Organizations in China: Mobilizing Rural Migrant Workers." Journal of Industrial Relations 55(2): 243-59.

ZHANG, Yueran. 2018. "The Jasic Strike and the Future of the Chinese Labour Movement." Made in China Journal 3(3): 12-7. 